\title{
REÁLNY PROCES AUTOMATICKEJ IDENTIFIKÁCIE TOVAROV A SLUŽIEB A TRANSFERU POZNATKOV - RFID LAB.
}

\author{
Peter Kolarovszki ${ }^{1}$, Juraj Vaculík ${ }^{2}$
}

\section{1. Úvod do problematiky - Automatická identifikácia a zber údajov}

Automatická identifikácia a zber údajov (AIDC) je kompaktný celok zaoberajúci sa metódami automatickej identifikácie objektov, následného zberu údajov a ich vkladania do počítačových systémov (bez priameho l'udského zásahu). Skupina technológií bezkontaktnej identifikácie AIDC je často titulovaná tiež ako automatická/bezkontaktná identifikácia, AutoID alebo automatický zber údajov.

AIDC predstavuje proces získavania externých údajov, obzvlášt' analýzou obrazu, zvuku alebo videa. Tieto dáta sú prostredníctvom snímača zozbierané a prevedené do digitálneho súboru. Zber údajov môže prebiehat' mnohými spôsobmi.

\subsection{Druhy automatickej identifikácie}

Medzi technológie typicky považované za súčast’ AIDC radíme čiarové kódy, rádio frekvenčnú identifikáciu (RFID), biometriu, magnetické štítky, optické rozpoznávanie (OCR Optical character recognition), alebo rozpoznávanie hlasu (voice recognition).

Počiatky automatickej identifikácie a RFID všeobecne spadajú až k tradičnej forme papierového označovania tovarov. Systémy papierového značenia boli v priemysle v 70-tych rokoch 20. storočia nahrádzané širokým spektrom technológií, súhrnne nazývaných AIDC.

Rádio frekvenčná identifikácia je len jednou čast'ou z tejto technologickej hierarchie. Okrem toho sem spadajú nám už vel'mi známe čiarové kódy (barcodes), ako aj optické rozpoznávanie (OCR - Optical character recognition) a technológie založené na identifikácii pomocou infračervených lúčov (Infrared identification technology), pozri obrázok 1. RFID možno nazvat' aj vychádzajúcou hviezdou v tejto rodine, resp. AIDC hierarchii, ktorá sa zdá byt' pripravená poskytnút' mnohé výhody zatial' ešte neponúkané inými technológiami.

\footnotetext{
${ }^{1}$ Ing. Peter Kolarovszki, PhD., Žilinská univerzita v Žiline, Fakulta prevádzky a ekonomiky dopravy a spojov, Katedra spojov, Univerzitná 8215/1, 01026 Žilina, Slovenská republika, tel.: +421 41513 3144, fax: +421 41565 5615, e-mail: Peter.Kolarovszki@fpedas.uniza.sk

2 Doc. Ing. Juraj Vaculík, PhD., Žilinská univerzita v Žiline, Fakulta prevádzky a ekonomiky dopravy a spojov, Katedra spojov, Univerzitná 8215/1, 01026 Žilina, Slovenská republika, tel.: +421 415133144 , fax: +421 41565 5615, e-mail: Peter.Kolarovszki@fpedas.uniza.sk
} 


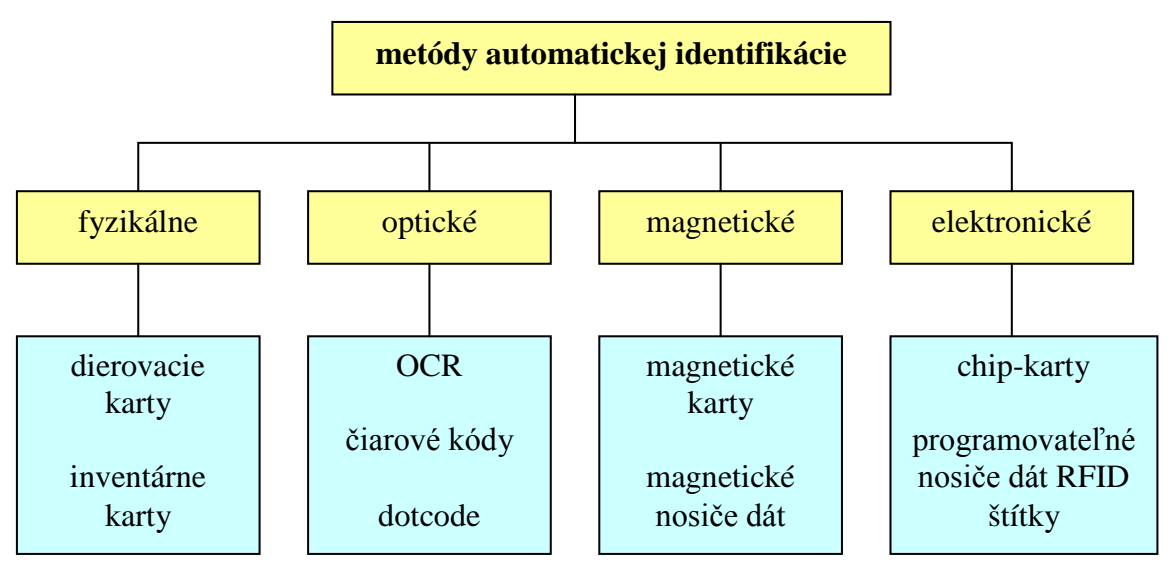

Obrázok 1 Metódy automatickej identifikácie (Zdroj: AT\&P journal. [online]. [Citované 2009-1412]. Dostupné na: <http://www.atpjournal.sk/pdf/2002_09_77-79.pdf>)

\section{2 . Charakteristika technológie RFID}

RFID predstavuje významný technologický postup v AIDC a tak ako čiarové kódy boli vol'akedy revolúciou tak aj RFID teraz patrí medzi novú generáciu v oblasti AIDC technológií., pretože ponúka výhody, ktoré nie sú k dispozícii v iných AIDC systémoch (napr. u čiarových kódov). Technológia rádio frekvenčnej identifikácie je jednou z foriem automatickej identifikácie a zberu údajov, ktorá je prezentovaná pod skratkou AIDC. Táto technológia využíva elektrické alebo magnetické polia využívajúce rádiové frekvencie na prenos informácií.

Každý predmet, ktorý je potrebné identifikovat', má vo vnútri prilepený alebo vtlačený malý objekt známy ako RFID štítok. RFID štítok má jedinečný identifikátor, prostredníctvom ktorého je možné uchovávat' dodatočné informácie o danom predmete. Prístroje, ktoré poznáme pod názvom RFID čítačky, bezdrôtovo komunikujú s RFID štítkami s úmyslom identifikovat' rovnako pripojené RFID štítky a s možnost'ou čítat' a aktualizovat' informácie, ktoré sú ukladané v RFID štítku.

Tieto charakteristiky znamenajú, že RFID technológia môže byt' realizovaná:

- Bez priamej (optickej) viditel'nosti, pretože rádiová vlna môže prechádzat' aj nepriehl'adným materiálom,

- Pri väčších rýchlostiach, pretože je možné čítat' vel'a štítkov za krátku dobu, zatial' čo optická AIDC požaduje časté premiestnenie tovaru v dôsledku nepriamej viditel'nosti a

- $\mathrm{Na}$ väčšie vzdialenosti, pretože mnohé z rádiových technológií pri prevádzkovom vyt’ažení umožňujú vysielanie a prijímanie signálov efektívnejšie ako optické AIDC.

Schopnost’ RFID technológie v rámci bezdrôtovej komunikácie, spojenia bez priamej viditel'nosti a na dlhé vzdialenosti umožňuje oproti iným AIDC technológiám zmenšit' potrebu človeka na identifikačnom procese. Napríklad, niekol'ko maloobchodných firiem má pilotný RFID program pre zistenie obsahu nákupného vozíka, bez vybratia položky nachádzajúcej sa vo vozíku a priloženia k čítaciemu zariadeniu. Toto je v súčasnosti príznačné pre mnohé zásobovacie sklady. V tomto prípade to umožňuje značné zrýchlenie doby obsluhy pri pokladni a tým zmenšenie prevádzkových nákladov pre maloobchodníkov. Toto použitie RFID má za následok aj významné zníženie doby obsluhy s pohl'adu zákazníka. 


\subsection{Základné komponenty RF subsystému}

V dôsledku aktivácie bezdrôtovej komunikácie pozostáva RF subsystém z RFID štítkov (tagov) a RFID čítačiek.

RFID štítky sú malé elektronické zariadenia, ktoré sú pripevnené k objektom, resp. vložené do nich. Každý štítok má unikátny identifikátor a môže mat’ aj iné prvky, ako napr. pamät’ pre skladovanie údajov, senzory týkajúce sa životného prostredia ako aj bezpečnostné, kryptovacie a šifrovacie prvky.

Základná charakteristika RFID štítku zahŕňa:

- Vel'kost' a tvar antény

- Zdroj napájania.

- Snímací rozsah

- Prevádzkové frekvencie

- Funkcionalita.

- Orientácia (polarizácia)

RFID štítky sú rozdelené v závislosti od zdroja napájania pre komunikáciu a inej funkcionality do štyroch kategórií:

- Pasívne.

- Aktívne.

- Polo - pasívne.

- Polo - aktívne.

RFID čitačky sú zariadenia bezdrôtovo komunikujúce s RFID štítkami, za účelom identifikácie položiek spojených so štítkom a s možnost'ou pridružit' označovanej položke príslušné údaje.

Štítok ako aj čítačka musia byt' za účelom dorozumievania prispôsobené rovnakým štandardom.

Vlastnosti RFID čítačiek, ktoré sú nezávislé na charakteristikách RFID štítku sú:

- výstupný výkon a pracovný cyklus RFID čítačky,

- prepojenie (rozhranie) s podnikovým podsystémom,

- mobilita,

- návrh a umiestnenie antény.

\section{Charakteristika RFID lab.}

RFID lab. Je skratkou pre laboratórium automatickej identifikácie tovarov a služieb. Jadrom celého systému pre identifikáciu tovarov a služieb prostredníctvom technológie RFID je systém SAP. Je to teda reálny systém, ktorý sa používa v praxi a prostredníctvom ktorého sa dajú logistické procesy simulované v laboratóriu reálne preukázat'. Formát údajov je podl'a štandardov GS1. Formáty sú definované v technických špecifikáciách a sú prístupné na používanie. Na rozlíšenie údajov sa používajú aplikačné identifikátory AI, na popisovanie tagov sa používa formát EPC - Electronic Product Code. Elektronický produktový kód môžeme charakterizovat' ako číslo zakódované $\mathrm{v}$ elektronickej podobe a uložené na pamätovom médiu - čipe. EPC je medzinárodne štandardizovaný systém, ktorý slúži na jednoznačnú identifikáciu tovaru a objektov v celom dodávatel'sko-odberatel'skom ret'azci. 
Laboratórium vzniklo na základe spolupráce partnerov z praxe ako aj akademickej sféry. Sú to nasledovný partnery:

- IdentCode

- Oriwin, s.r.o.

- Macro Components,

- Gaben, s.r.o.
- ŽU fakulta PEDAS

- Kodys, s.r.o.

- Vectra, s.r.o.

Laboratórium automatickej identifikácie tovarov a služieb má slúžit' na prezentáciu technológiu RFID $\mathrm{v}$ rôznych častiach distribučného ret'azca a poskytovat' priestor pre partnerské firmy na odskúšanie aplikácií pre svojich zákazníkov. Takisto má RFID lab. za ciel' spolupracovat' s vysokými školami na riešení projektov vlastného výskumu a vývoja, ako aj vytvorit' priestor na riešenie spoločných projektov. Ako sme už vyššie spomínali Žilinská Univerzita v Žiline, Fakulta prevádzky a ekonomiky dopravy a spojov je jedným z partnerov tohto laboratória a je zastúpená členmi z Katedry spojov.

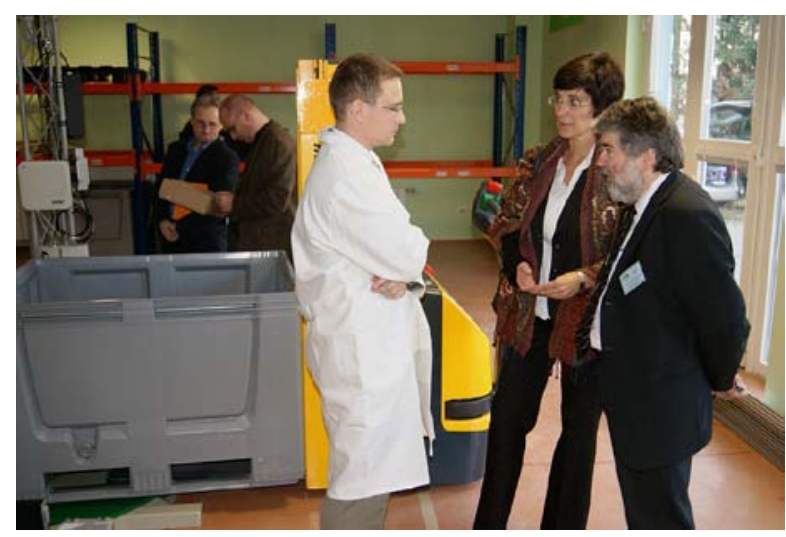

Obrázok 2 Zastúpenie ŽU v rámci RFID lab.

\subsection{Popis základných procesov a zariadení}

Hlavným ciel'om laboratória pre automatickú identifikáciu tovarov a služieb je prezentovat' technológiu RFID v nasledovných procesoch:

- Príjem materiálu - zadaného zo systému SAP

- Aplikovanie RFID etikiet na požadovaný materiál

- simulácia výroby (SAP, aplikátor, brána) a hotových výrobkov

- označovanie paliet a prepraviek prostredníctvom SmartLabels

- paletizácia a balenie

- skladové hospodárstvo (zaskladnenie tovaru, kontrola úplnosti, preskladnenie a vyskladnenie)

- simulácia predajne s podporou RFID 


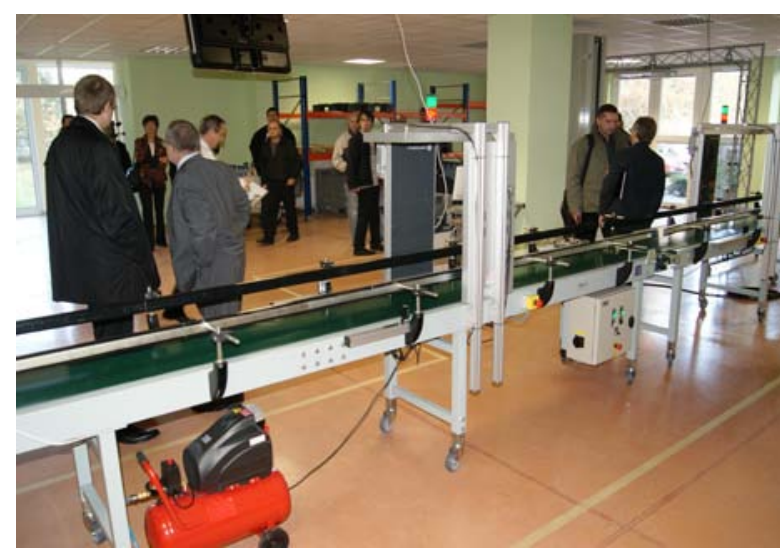

Obrázok 3 Čast' komponentov RFID lab.

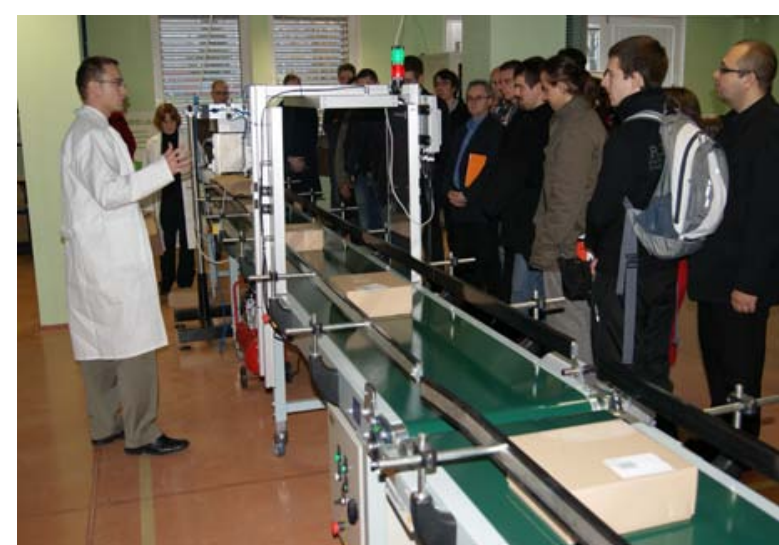

Obrázok 4 Prezentácia procesov RFID lab.

\subsubsection{Priebeh procesov identifikovania tovaru v RFID lab.}

\section{1. krok - Od príjmu materiálu po aplikovanie etikiet na tovar}

Celý proces identifikácie tovaru sa začína vybraním množstva a druhu materiálu zo systému SAP. Po vykonaní tejto operácie príjme tlačiareň informácie o obsahu a dizajne štítka.

Obsah riešenia:

- Design „template“ etikety škatule (ZPL)

Template etikety obsahuje nasledovné údaje :

o v textovej forme

- Názov výrobku (20 alfanumerických znakov)

- Batch Number (10 alfanumerických znakov)

- Dátum výroby (RRMMDD - 6 numerických znakov)

- Sériové číslo škatule (4 numerické znaky)

o čiarový kód EAN13 (pre číslo výrobku, pridelené v SAP ERP)

(čiarový kód musí byt' v súlade s ISO/IEC 15420)

o RFID tag - EPC formát 96-bitový (GTIN (číslo výrobku) + sériové číslo)

- Nakonfigurovanie parametrov pre RFID tlač a nastavenie tlačiarne pre siet'ovú tlač

Proces:

- Transakcia v systéme SAP pre tlač etikiet pre výrobu

o Zadat' je možné:

- EAN číslo výrobku (sériové číslo výrobku bude generované systémom SAP ERP)

- šarža

- počet výrobkov - škatúl'

o Zaslanie údajov o výrobku a počte škatúl' na tlačiareň ZEBRA (aplikátor) v ZPL jazyku [4]

V sektore, ktorý simuluje výrobu a následnú paletizáciu je dopravníkový pás, po ktorom sa pohybujú produkty. Pri páse je nainštalovaná tlačiareň štítkov na označenie výrobku. Etiketu vytlačí tlačiareň a zakóduje do tagu EPC číslo. Takto vytlačenú etiketu nalepí aplikátor na škatul’u (krabicu). Následne sa rozbehne dopravný pás.

\section{2. krok - od sektora výroby po paletizáciu}


Snímanie tagov na škatuliach , ktoré sú úspešne vytlačené a aplikátorom prilepené na škatul'u vykonáva RFID brána na konci sektora na prvom páse. Výsledky kontroly sa prenášajú do informačného systému SAP a porovnávajú sa so zadanými požiadavkami na produkciu.

- Zavolaním webovej služby sa vykoná v systéme SAP zaevidovanie prechodu konkrétnej škatule cez príslušnú bránu - podl’a jednoznačného tagu sa prevezmú údaje:

o množstvo

o šarža

- V systéme SAP sa zobrazí report zobrazujúci:

o výrobky zadané do výroby

o príznak kontroly výrobku v škatuli, ktorý sa prečítal cez bránu

Do sektora hotových výrobkov prichádzajú označené škatule z predchádzajúceho procesu. Nasleduje zosnímanie týchto výrobkov (škatúl'), prostredníctvom RFID brány. Údaje z RFID brány sa prenášajú do informačného systému a zaznamenávajú sa ako hotové výrobky, ktoré opustili sektor výroby a sú pripravené na zaskladnenie. V sektore na konci pásu padajú do ohradovej palety. Dáta na paletovom tagu sú nahraté vopred DATAMAX tlačiarňou.

- Zavolaním webovej služby sa vykoná v systéme SAP príjem na sklad načítaných škatúl' s jednotlivými výrobkami a šaržami. Podl'a jednoznačného tagu škatúl' sa prevezmú údaje: číslo výrobku, množstvo, šarža

- V systéme SAP ERP vznikne materiálový doklad so sumárnym množstvom zabalených výrobkov

- V systéme SAP ERP vznikne na rozhraní sumárne množstvo výrobkov a šarží v zóne príjmu materiálu do riadeného skladu.

- V systéme SAP budú nasledovné reporty:

o Zoznam výrobkov v zóne príjmu

o Zoznam materiálových a účtovných dokladov (doklady množstevnej evidencie príjmu výrobku do skladu)

\section{Vstup hotových výrobkov do skladu - bod paletizácie}

Naplnená paleta označená ručne etiketou z tlačiarne DATAMAX s tagom čísla prechádza do sektoru skladu. Paleta sa vozíkom prevezie z konca pásu cez RFID bránu. Tu sa priradí prečítaný tag z palety k obsahu palety. Dostaneme jednoznačnú identifikáciu a s ňou vstupujeme do skladu. Ak sa počet výrobkov z čítania v sektore hotových výrobkov nebude zhodovat' s počtom prečítaných RFID bránou vbode paletizácie zapne sa ovinovačka a točením palety $\mathrm{v}$ čítacom poli brány sa pokúsi prečítat' všetky tagy na výrobkoch škatuliach. V procese bude pokračovat' iba počet, ktorý sa načíta $v$ tejto bráne. Tu dostaneme odpoved' na otázku: Sú tam všetky výrobky alebo sa nejaký stratil?

- Zavolaním webovej služby sa vykoná v systéme SAP „zabalenie“ načítaných škatúl' s jednotlivými výrobkami a šaržami do konkrétnej palety. Podl'a jednoznačného tagu škatúl' sa prevezmú údaje: výrobok, množstvo, šarža

- V systéme SAP vznikne paleta v zóne príjmu materiálu do riadeného skladu - číslo palety bude zhodné s číslom tagu z etikety,

- V systéme SAP budú nasledovné reporty: 
o Zoznam paliet v bode paletizácie

o Zoznam skladových príkazov (dokladov o paletizácii)

\section{3. krok Riadenie skladu}

V tomto priestore sa simuluje riadenie skladu, kontrola skladových zásob, automatické zaskladňovanie a vyskladňovanie, inventúra zásob a orientácia $\mathrm{v}$ sklade pomocou rádiofrekvenčnej identifikácie v kombinácii s čítaním čiarových kódov pre označenie regálov.

o operácia zaskladnenie do riadeného skladu regálu

- Na termináli sa vyberie operácia zaskladnenie, načíta sa cez RFID snímač číslo palety na zaskladnenie a tiež ciel'ové skladové miesto cez čiarový kód, vykoná sa kontrola na umiestnenie palety v zóne príjmu materiálu.

- Na základe zadaných údajov sa v systéme SAP ERP vytvorí skladový príkaz a materiál umiestnený na palete sa spolu s paletou preskladní na nové skladové miesto.

o operácia preskladnenie v rámci riadeného skladu

- Na termináli sa vyberie operácia preskladnenie, načíta sa cez RFID snímač číslo palety na preskladnenie a tiež ciel'ové skladové miesto cez čiarový kód.

- Na základe zadaných údajov sa v systéme SAP ERP vytvorí skladový príkaz a materiál umiestnený na palete sa spolu s paletou preskladní na nové skladové miesto.

o operácia vyskladnenie - výdaj na nákladové stredisko

- Na termináli sa vyberie operácia vyskladnenie, načíta sa cez RFID snímač číslo palety a vyberie - zadá číslo nákladového strediska.

- Na základe zadaných údajov sa v systéme SAP ERP vytvorí skladový príkaz a materiálový doklad a materiál umiestnený na palete sa vyskladní a paleta v systéme zanikne. [4]

\section{Literatúra}

[1] LEHPALMER H. RFID design principles. Norwood (USA):Artech House Publishing, 2008.

[2] ANDRECHAK, WILSON, ZIMMARDI, RFID Item Level Management, Mullaney publishing group, 2007

[3] SHEPARD S. RFID: Radio frequency Identification. New York (USA), McGraw-Hill Publishing, 2005

[4] Blueprint - Interný materiál pre RFID lab. , vypracovaný spoločnost’ou ORIWIN. 